\title{
Epidemiological and occupational profile of eye trauma at a referral center in Espírito Santo, Brazil
}

\author{
Aspectos epidemiológicos e trabalhistas do trauma ocular \\ em um centro de referência no Espírito Santo, Brasil
}

Miquele Milanez¹, Patricia Grativol Costa Saraiva ${ }^{1}, N^{1}$ atalia Nunes Barcellos ${ }^{1}$, Fábio Petersen Saraiva ${ }^{1}$

\begin{abstract}
Objective: To draw an epidemiological and occupational profile of eye trauma at a Brazilian referral center, make comparisons with the literature and provide subsidies for the adoption of adequate prevention and enforcement measures. Methods: Descriptive and prospective epidemiological study using a standardized questionnaire to collect data from 60 patients presenting with eye trauma at an ophthalmology service (HUCAM) between 1 april 2013 and 1 october 2013. Results: The male gender was predominant (80\%). Ages ranged from 8 to 60 years. Most accidents $(56.7 \%)$ occurred in the workplace, followed by the home $(28.3 \%)$. Most injuries were closed, predominantly contusions, followed by foreign body on the external eye. Importantly, $82.9 \%$ of the victims of work-related trauma wore no eye protection at the time of the accident. Conclusions: Eye trauma in the workplace and elsewhere is an important problem of public health as it affects primarily the economically active population and may have serious consequences. A considerable proportion of eye trauma is easily avoidable by using personal protective equipment. To minimize the incidence of eye trauma, more attention should be given to instruction in and enforcement of the use of such equipment, supported by frequent prevention campaigns.
\end{abstract}

Keywords: Eye injuries/epidemiology; Accidents, occupational/epidemiology; Personal protective equipment; Brazil

\section{ReSUMO}

Objetivo: Caracterizar os aspectos trabalhistas e epidemiológicos regionais envolvidos no trauma ocular, comparar os dados obtidos com os já publicados na literatura e fornecer subsídios para a elaboração de medidas de prevenção e fiscalização adequadas. Metodologia: Estudo epidemiológico, descritivo, prospectivo, realizado no serviço de Oftalmologia do HUCAM, em 60 pacientes com trauma ocular, no período de 01 de abril a 01 de outubro de 2013, quando foram colhidos dados, por meio de questionário padronizado. Resultados: Houve predomínio de indivíduos do sexo masculino $(80 \%)$ e em sua maioria os pacientes tinham idades que variavam entre 8 e 60 anos. Predominaram os acidentes no ambiente de trabalho (56,7\%) seguido dos acidentes domiciliares $(28,3 \%)$. A maioria dos traumas foi do tipo fechado, com predomínio das contusões seguidas pelo corpo estranho na superfície ocular. Observou-se também que $82,9 \%$ dos pacientes que tiveram o trauma no ambiente de trabalho não usavam o equipamento de proteção individual. Conclusões: Trauma ocular é um importante problema de saúde pública, pois acomete principalmente a população economicamente ativa e pode ter graves consequências. Grande parte destes acidentes poderiam ser facilmente prevenida através do uso apropriado de equipamentos de proteção individual. Desta forma, orientação, fiscalização para o fornecimento e uso dos EPIs e campanhas de prevenção são importantes para redução desses acidentes.

Descritores: Traumatismos oculares/epidemiologia; Acidentes ocupacionais/epidemiologia; Equipamento de proteção individual; Brasil

${ }^{1}$ Specialized Medicine Department - Universidade Federal do Espírito Santo, Vitória (ES), Brazil. Os autores declaram não haver conflitos de interesse.

Recebido para publicação em 11/08/2016 - Aceito para publicação em 12/10/2016 


\section{INTRODUCTION}

A common occurrence, eye trauma is a major cause of avoidable blindness worldwide ${ }^{(1)}$, although loss of vision is rarely bilateral ${ }^{(2)}$. An estimated $27 \%$ of victims of eye trauma have a visual acuity (VA) of less than 20/200(3). Despite the importance of eye trauma to public health, little information is available regarding causes, risk factors, incidence and severity of accidents. ${ }^{(4)}$ Eye trauma is generally more common in young males. A significant percentage is associated with occupational accidents, defined as a discrete occurrence in the course of work causing bodily injury and/or permanent or temporary functional impairment leading to partial or complete loss of ability to work, or death ${ }^{(5)}$. Accidents occurring when commuting are also considered work-related provided the route taken remains the same. Since most victims of eye trauma are young and/or economically active, the economic and occupational consequences are significant. In fact, even though work-related eye injuries are often superficial, the costs associated with treatment and absence from work are high ${ }^{(4)}$. Evidence has shown that eye trauma is not a chance event and that some occupations are associated with particular risks. Not surprisingly, a considerable proportion of eye trauma is avoidable simply by wearing proper eye protection. ${ }^{(1,6)}$

In 2012, approximately 705,200 occupational accidents were reported in Brazil, of which 2,759 were classified as ICD (international classification of diseases) S05 (injury of eye and orbit) and 5,364 were classified as ICD T15 (foreign body on external eye). According to data provided by the Brazilian Social Security, in 2011 the incidence of occupational accidents and ICD S05 decreased by $2.14 \%$ and $4.56 \%$, respectively, whereas the incidence of ICD T15 increased by $11.59 \%{ }^{(5)}$. These annual statistics do not include all work-related eye injuries but only accidents involving workers protected by the labor legislation (CLT). In addition, severe accidents are more likely to be reported $^{(7)}$. The World Health Organization (WHO) estimates that each year 55 million eye injuries are responsible for the loss of at least one day of activity ${ }^{(8)}$. In the US, over fifty percent of work-related eye injuries occur in the sectors of manufacturing, services and construction. Eighty percent of these accidents involve male workers aged 25-44 years $^{(9)}$.

According to the Birmingham Eye Trauma Terminology (BETT), eye trauma may be classified into open globe injury (full-thickness wound of the eyewall, including cornea and sclera) and closed globe injury (no full-thickness wound of eyewall) ${ }^{(10)}$. The latter is subdivided into contusion (caused by a blunt object) and lamellar laceration (partial-thickness wound of the eyewall). The former is subdivided into rupture (caused by a blunt object) and laceration (caused by a sharp object). Again, lacerations may be subdivided into penetrating injury (entrance wound only), perforating injury (both entrance and exit wounds), and penetrating injury with retained foreign object.

The purpose of this study was to evaluate the profile of eye trauma patients attending an ophthalmology service (HUCAM) in a brazilian state capital with regard to gender, occupation, age, homestead, place of accident, type of employment contract, history of eye trauma, submission of occupational accident report (CAT) to the authorities, and use of personal protective equipment (PPE). To our knowledge, no previous study has investigated the epidemiological and occupational aspects of eye trauma in Brazil. The collected information was used to expand current epidemiological knowledge of eye trauma in the region, make comparisons with the literature and provide subsidies for the adoption of adequate prevention and enforcement measures.

\section{MethOdS}

In this descriptive and prospective epidemiological study, we used a standardized questionnaire to collect data from 60 patients presenting with eye trauma at our ophthalmology service (HUCAM, Vitória, Espírito Santo, Brazil) between 1 april 2013 and 1 october 2013. All participants gave their informed written consent.

All consultations were given by resident physicians at our ophthalmology service trained and supervised by a senior ophthalmologist. Following the consultation, the patients were invited to participate in the study. The participants were fully informed about the study protocol and were free to skip unwanted questions. The questionnaire collected information on gender, age, occupation, type of employment contract, affected eye, place of occupational accident, history of eye trauma, submission of occupational accident report (CAT) to the authorities (current and previous injuries), use of PPE, type of PPE, instruction in and inspection of PPE use, type of injury, previous treatments, and reporting of accident to internal safety and accident prevention committee (CIPA) or to management.

Eye injuries were classified according to the BETT terminology. Initially, all variables were analyzed descriptively and absolute and relative frequencies were calculated for the classificatory variables. Differences in proportions were analyzed with the chi-square test and Fisher $1 / 4$ s exact test. ${ }^{(11)}$ All analyses were performed with the software SPSS 17.0 for Windows. The level of statistical significance was set at $5 \%(p<0.05)$.

\section{Results}

During the six-month study period, 60 patients (62 eyes) were included in the study. Unilateral injuries affected the right eye $(n=31)$ or the left eye $(n=27)$. Two patients presented with bilateral injury. Most patients $(80 \%)$ were male (male/female ratio $4: 1$ ). On the average, patients were aged 34.8 years (range: 8-60). The age groups 21-35 years and 36-50 years were represented by 18 patients each, corresponding to $30 \%$ of all cases in each category.

More than half the accidents $(n=35 ; 56.7 \%)$ occurred in the workplace, followed by the home $(n=17 ; 28.3 \%)$ and the street (Figure 1). Closed globe injuries were most frequent $(n=36$; $66.7 \%)$, usually from blunt objects $(51.4 \%)$ or foreign bodies on the ocular surface $(45.9 \%)$. When analyzed with Fisher $1 / 4$ s test, the two categories (open vs. closed globe injury) did not differ significantly with regard to gender, age or occupation.

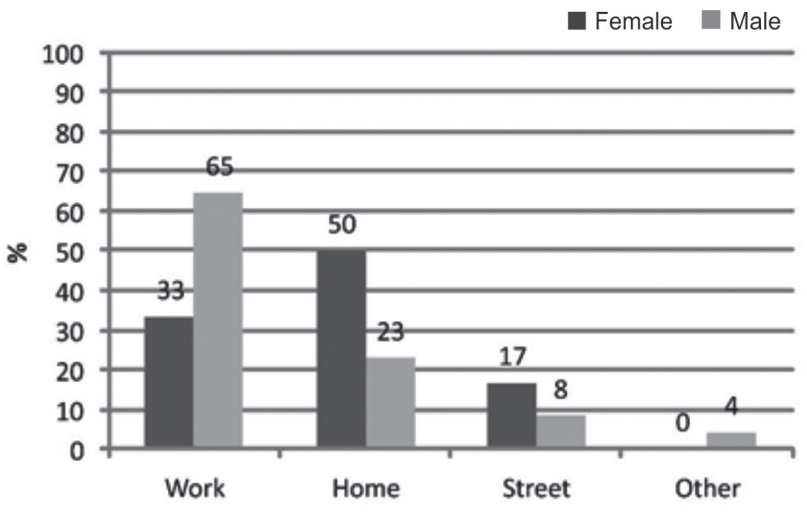

Figure 1: Distribution of place of accident according to gender 
The male gender was predominant in non-work-related eye trauma $(n=17 ; 68 \%)$. In this group of patients the average age was only 27 years (range: $8-58$ ) due to the greater proportion of minors under $21(\mathrm{n}=12 ; 48 \%)$. The male gender was even more predominant in work-related eye trauma $(88.6 \%)$. In this group of patients, the average age was 40.3 years, with $40 \%$ in the range $36-50$ years (Figures 2 and 3$)$. Significant correlations $(\mathrm{p}<0.05)$ were found between the place of accident (work-related or nonwork-related) and the age group ( $36-50$ years or $<21$ years). Workrelated eye trauma was also significantly associated with the male gender $(\mathrm{p}=0.0495)$.

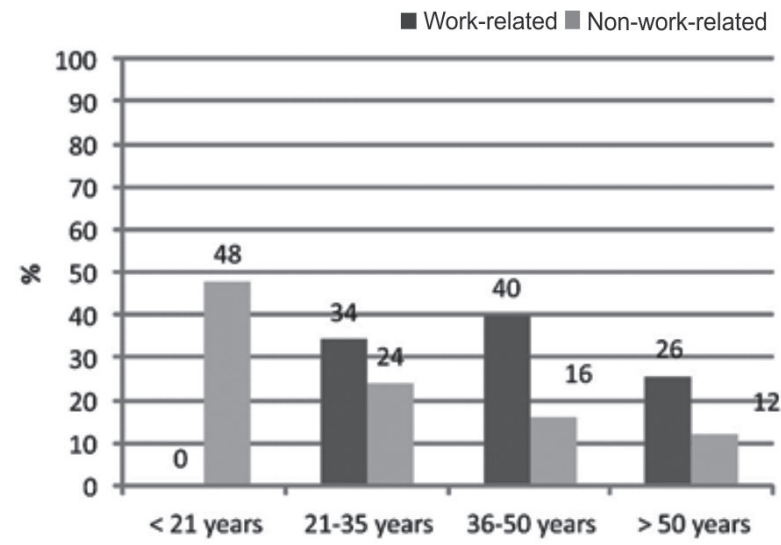

Figure 2: Distribution of eye trauma according to age group and place of accident

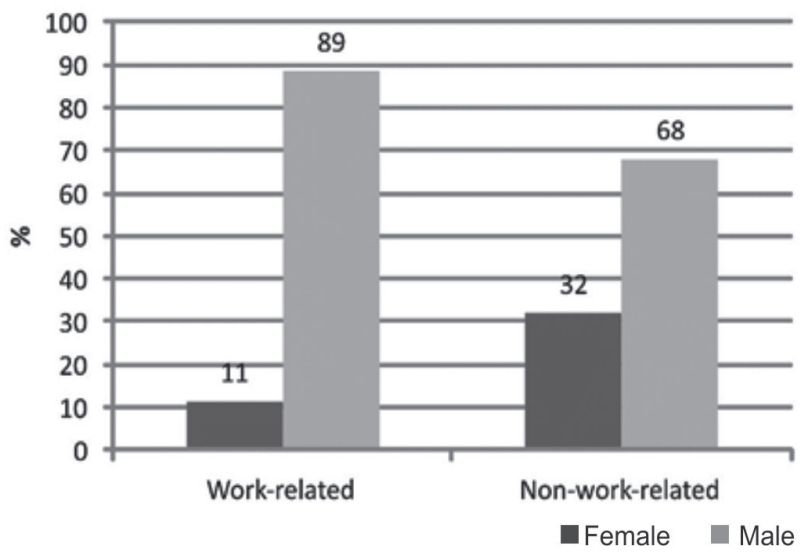

Figure 3: Distribution of eye trauma according to gender and place of accident

Among non-work-related trauma, 92.3\% were mechanical and $7.7 \%$ were chemical in nature. Among the former, $70.8 \%$ were closed globe injuries, of which $58.8 \%(n=10)$ were classified as contusions, $35.3 \%(n=6)$ as foreign body on the ocular surface, and $5.9 \%(n=1)$ as both.

Work-related eye trauma occurred predominantly in the construction sector (31.4\%). Farm workers accounted for $20 \%$, metalworkers for $8.6 \%$ and other occupations (mechanics, janitors, nursing assistants, warehouse and slaughterhouse staff) for $37.2 \%$. Among patients with work-related accidents, $54.3 \%$ had officially registered (formal) employment. The most common type of injury among workers was corneal abrasion (28.5\%), followed by corneal penetration $(17.1 \%)$, traumatic cataract and corneal ulcer $(14.3 \%$ each). Nine $(25.7 \%)$ of the 35 victims of work-related accidents had a history of eye trauma (77.8\% males). In three of these, employment was formal, but no occupational accident report was filed.

Closed globe injury by contusion resulted in corneal ulcer $(n=6)$, subconjunctival hemorrhage $(n=3)$, traumatic cataract $(n=2)$, corneal laceration, corneal de-epithelialization, punctate keratitis, traumatic uveitis, vitreous hemorrhage, shallow anterior chamber, poor visual acuity, glaucoma and pharmacological mydriasis $(n=1$ each). Open globe injury was associated with corneal penetration $(n=6)$, traumatic cataract $(n=5)$, iris hernia $(n=3)$, phthisis bulbi $(n=2)$, amaurosis, total retinal detachment and scleral perforation $(\mathrm{n}=1$ each).

The majority of victims of work-related eye trauma $(n=29$; $82.9 \%$ ) wore no eye protection at the time of the accident, although $48.6 \%$ were instructed to do so and $28.6 \%$ reported being subject to on-the-job PPE inspection. Fifteen (88.2\%) of the subjects who were instructed to wear PPE were in a situation of formal employment. Six subjects wore eye protection at the time of the accident. Of these, $83.3 \%$ were in a situation of formal employment and $66.7 \%$ were instructed in PPE use and subject to on-the-job PPE inspection (Table 1). PPE-related instruction and inspection was more frequently reported by patients who held formal jobs.

Nineteen of the 35 victims of work-related eye trauma had formal employment, but the authorities were only notified by CAT in three cases $(15.7 \%)$, whereas $73.6 \%$ of the accidents were reported to an internal committee (CIPA) or to the management.

\section{DisCUSSION}

The predominance of the male gender in our sample was no surprise. Men are more vulnerable to eye trauma due to their greater participation in economic activities with increased risk of eye trauma and their greater proneness to risk behaviors, such as relaxing safety measures and disregarding the use of $\mathrm{PPE}^{(4,8,12-16)}$.

The average age of our patients was 34.8 years, matching earlier studies in which prevalence peaked in the age range 30 35 years. More than half the observed eye injuries $(56.7 \%)$ occurred when the patient was performing an activity pertaining to his/her function, regardless of whether employment was formal or informal ${ }^{(4,7,16)}$.

The male gender was predominant $(88.6 \%)$ among victims of work-related injuries. This is supported by two other Brazilian studies showing incidences between 88.1 and $96.21 \%{ }^{(14,15)}$ and by a study from Glasgow $(98.8 \%)^{(4)}$. The occupational sector most strongly associated with eye trauma was construction ${ }^{(4,7,12,14)}$.

Most of our cases $(66.7 \%)$ were classified as closed globe injury, mainly from blunt objects $(51.4 \%)$ and foreign objects on the ocular surface $(45.9 \%)$. Nevertheless, the frequency of open globe injury (34.3\%), especially in the form of corneal penetration $(17.1 \%)$, was particularly high in this study, contradicting the findings of several other brazilian and international studies showing a greater prevalence of foreign objects on the ocular surface $(54.6-81.8 \% \text { of eye injuries })^{(1,4,12,14,15)}$. This is probably because, as a tertiary-level referral center, our service tends to receive the most severe cases, while simpler cases may be referred to a range of local ophthalmology clinics, thereby introducing a category bias. We believe underreporting at our service may be ruled out as an explanation since all the resident physicians with access to first consultations of cases of eye trauma were carefully trained and continually held accountable for their performance against a standard protocol.

Although $48.6 \%$ of the injured workers were aware of the need to wear eye protection, no PPE was worn at the time of the accident in $82.9 \%$ of cases, matching findings from 
Brazilian and international studies ${ }^{(2,4,7,15,16)}$. Based on these observations, two conclusions may be drawn: 1) the PPE was not appropriate for the task or was incorrectly used in $17.1 \%$ of cases, since eye trauma occurred despite the presence of protective gear; 2) a considerable proportion of workers are not wearing the PPE required by the nature of their work. This may occur because the PPE is perceived to be uncomfortable or to restrict vision, or because safety measures are ignored or disregarded. Educational campaigns and enforcement of PPE use on part of both employers and local representatives of the Ministry of Labor and Employment, as recommended by the International Labor Organization and by the Brazilian labor legislation (NR\#6), should be more frequent and emphatic in order to minimize the incidence of work-related eye injuries. Importantly, current Brazilian legislation (NR\#9) specifies that PPE should not only be technically appropriate but also comfortable, according to the evaluation of the user. Even perfectly protective equipment is useless if workers refuse to wear it for reasons of discomfort.

An important and unique finding of this study is that the authorities were notified of only $15.7 \%$ of work-related eye injuries affecting workers with formal employment, although $73.6 \%$ reported having informed their respective management or internal safety committee. This points to a considerable level of underreporting in the database of the Brazilian Social Security. According to Social Security regulations, the filing of an occupational accident report (CAT) by the employer is mandatory up to one day after a work-related accident. In the absence of such submission, the workers' trade union, the attending physician, public agencies (such as the Workers' Referral Center for Occupational Health/CEREST), the worker him/herself or his/her representative can file a CAT at any moment (Decree \#3048/99) ${ }^{(17)}$. On the other hand, it should be kept in mind that the present study was based on information provided by patients through questionnaires and that the collected information could not be verified either by technical visits to companies or by consultation with government agencies handling occupational accident reports.

Eye trauma associated with accidents in the home and on the street was particularly prevalent in younger subjects: $12(48 \%)$ injuries were observed in minors under 21 . The injuries were less severe (subconjunctival hemorrhage, foreign body on the ocular surface and corneal de-epithelialization) in only 4 of these. The high prevalence in this age group may be explained by our institution $1 / 4 \mathrm{~s}$ role as referral center in the state of Espírito Santo for children with eye trauma, offering emergency care and ophthalmological surgery under general anesthesia. Three minors in our sample presented with corneal penetration, two had phthisis bulbi and one was treated for retinal detachment, suggesting children and adolescents are particularly susceptible to severe eye trauma ${ }^{(4)}$. In addition, due to a pattern of physical and recreational activity, younger subjects are at increased risk of closed trauma such as contusion ${ }^{(15)}$.

\section{CONCLUSION}

Eye trauma in the workplace and elsewhere is an important problem of public health as it affects primarily the economically active population and may have serious consequences, including blindness. However, a considerable proportion of eye trauma could be avoidable by using PPE. Therefore, more attention should be given to instruction in and enforcement of the use of such equipment, supported by frequent prevention campaigns in the workplace and in schools. In addition, authorities are advised to alert companies to the importance of routinely reporting eye trauma by filing mandatory occupational accident reports, thereby minimizing the current problem of underreporting.

\section{RefERENCES}

1. Fiebai B, Awoyesuku E. Ocular injuries among industrial welders in PortHarcourt, Nigeria. Clin Ophthalmol. 2011;5:1261-3.

2. McCarty CA, Fu CL, Taylor HR. Epidemiology of ocular trauma in Australia.Ophthalmology. 1999 Sep;106(9):1847-52.

3. Kuhn F, Morris R, Witherspoon CD, Mann L. Epidemiology of blinding trauma in the United States Eye Injury Registry. Ophthalmic Epidemiol. 2006;13(3):209-16.

4. Macewen CJ. Eye injuries: a prospective survey of 5671 cases. $\mathrm{Br}$ J Ophthalmol. 1989;73(11):888-94.

5. Brasil. Ministério da Previdência Social. Anuário Estatístico da Previdência Social 2012 [Internet]. [citado 2014 Mai 6]. Disponível em: http://www.previdencia.gov.br/wp-content/uploads/2013/05/AEPS_2012.pdf

6. Slade MP. Ocular trauma. Aust N Z J Surg. 1999;69(8):582-3.

7. Gerente VM, Melo GB, Regatieri CV, Alvarenga LS, Martins EN. [Occupationaltrauma due to superficial corneal foreign body]. Arq Bras Oftalmol. 2008;71(2):149-52. Portuguese.

8. Cecchetti DF, Cecchetti SA, Nardy AC, Carvalho SC, Rodrigues Mde L, Rocha EM. [A clinical and epidemiological profile of ocular emergencies in a reference emergency center]. Arq Bras Oftalmol. 2008;71(5):635-8. Portuguese.

9. Peate WF. Work-related eye injuries and illnesses. Ann Fam Med. 2007;75(7):1017-22.

10. Kuhn F, Morris R, Witherspoon CD, Mester V. The Birmingham Eye Trauma Terminology system (BETT). J Fr Ophtalmol. 2004;27(2):206-10. Review.

11. Rosner B. Fundamentals of biostatistics. Boston, PWS Publishers. Second edition, 1986.

12. Araújo AA, Almeida DV, Araújo VM, Góes MR. Urgência oftalmológica: corpo estranho ocular ainda como principal causa. Arq Bras Oftlamol. 2002; 65(2):223-7.

13. Wong TY, Klein BEK, Klein R. The prevalence and 5-year incidence of ocular trauma. Ophthalmology. 2000; 107(12):2196-202.

14. Leal, FAM, Silva Filho AP, Neiva DM, Learth JC, Silveira DB. Trauma ocular ocupacional por corpo estranho superficial. Arq Bras Oftalmol. 2003; 66(1):57-60.

15. Andrade AS, Siqueira Bisneto O, Moreira H, Moreira CA. Traumas oculopalpebrais no serviço de pronto-atendimento oftalmológico do Hospital Universitário Evangélico de Curitiba. Arq Bras Oftalmol. 1999; 62(5):585-9.

16. Soong TK, Koh A, Subrayan V, Loo AV. Ocular trauma injuries: a 1-year surveillance study in the University of Malaya Medical Centre, Malaysia. 2008. Graefes Arch Clin Exp Ophthalmol. 2011; 249(12):1755-60.

17. Brasil. Decreto $n^{\circ} 3048$, de 06 de maio de 1999. Aprova o Regulamento da Previdência Social, e dá outras providências [Internet]. [citado 2016 Out 9]. Disponível em: http:// www.planalto.gov.br/ccivil_03/decreto/d3048.htm

\section{Corresponding Author:}

Fábio Petersen Saraiva

Departamento de Medicina Especializada/CCS/UFES

Av. Marechal Campos, n 1468 - Maruípe

Zip Code: 29047-105 - Vitória (ES), Brazil

Phone/Fax: 55(27) 3335-7221

Email: fabiopetersen@yahoo.com.br 